\title{
ANALISIS PENGARUH KARAKTERISTIK KOMITE AUDIT TERHADAP KETERLAMBATAN AUDIT PADA PERUSAHAAN YANG TERDAFTAR DI BURSA EFEK INDONESIA
}

\author{
Budi Chandra ${ }^{1 *}$, Kellin ${ }^{2)}$ \\ ${ }^{1}$ Fakultas Ekonomi, Universitas Internasional Batam \\ email: budi.chandra@uib.ac.id \\ ${ }^{2}$ Fakultas Ekonomi, Universitas Internasional Batam \\ email: kellinkell@gmail.com
}

\begin{abstract}
This research interprets the relation of audit committee characteristics on audit delay in corporations or companies registered in Indonesia Stock Exchange year 2014-2018. The used independent variables are audit committee financial expertise, audit committee independency, audit committee size, audit committee meetings, audit committee charter, profitability, company size, ownership concentration, auditor switching, auditor opinion, political connection and auditor specialized in industry. Sample of this research includes 446 out of 649 companies with grand total of 1.720 observation data obtained. The technique to gather samples are based on methods of selecting certain pre-determined criteria. Following research data later tested with aid of SPSS 22 and Eviews 10. Research concludes that audit committee size, company size and profitability have significant negative effect, while on the other hand audit opinion has significant positive effect on audit delay. Audit committee financial expertise, audit committee independency, audit committee meetings, audit committee charter, ownership concentration, auditor switching, political connection and auditor specialized in industry variables do not have significant influence towards audit delays.
\end{abstract}

Keywords: Audit committee characteristics, audit delay

\begin{abstract}
ABSTRAK
Penelitian ini menafsirkan hubungan karakteristik komite audit terhadap keterlambatan audit pada perusahaan-perusahaan yang terdaftar di Bursa Efek Indonesia tahun 2014-2018 dengan penggunaan variabel independen yakni keahlian keuangan komite audit, independensi komite audit, ukuran komite audit, pertemuan komite audit, piagam komite audit, profitabilitas, ukuran perusahaan, konsentrasi kepemilikan, pergantian auditor, opini audit, koneksi politik, dan auditor spesialis industri. Sampel penelitian ini mencakup 446 dari 649 perusahaan dengan jumlah akhir 1.720 data observasi yang diperoleh. Teknik pengumpulan sampel berdasarkan metode penetapan sejumlah kriteria yang telah ditentukan. Data penelitian selanjutnya diuji melalui bantuan program SPSS 22 dan Eviews 10. Hasil dari penelitian menyimpulkan ukuran komite audit, ukuran perusahaan dan profitabilitas berpengaruh signifikan negatif, sedangkan opini audit memiliki pengaruh signifikan positif terhadap keterlambatan audit. Variabel keahlian keuangan komite audit, independensi komite audit, pertemuan komite audit, piagam komite audit, konsentrasi kepemilikan, pergantian auditor, koneksi politik, dan auditor spesialis industri tidak memiliki pengaruh signifikan terhadap keterlambatan audit.
\end{abstract}

Kata Kunci: Karakteristik komite audit, keterlambatan audit 


\section{PENDAHULAN}

Suatu informasi keuangan yang berguna dan berkualitas memiliki beberapa karakteristik, salah satunya adalah ketersediaan informasi yang tepat waktu. Keakuratan masa waktu menyampaikan laporan keuangan dipercaya merupakan satu bagian dari dasar penentu utama suatu laporan keuangan yang berkualitas, yang mana juga merupakan hal yang diperhatikan dalam prinsip keterbukaan tata kelola perusahaan (Güleç, 2017). Sangat penting bagi tokoh dalam maupun tokoh dari luar perusahaan memperoleh laporan dalam waktu yang pendek karena akan hilangnya nilai informasi yang terkandung pada laporan keuangan jika tidak didapatkan ketika dibutuhkan dalam pengambilan keputusan (Arifa, 2013).

Handayani dan Yustikasari (2017) berpendapat bahwa untuk meminimalisir keterlambatan penyampaian laporan keuangan, memiliki tata kelola perusahaan menjadi keperluan bagi sebuah perusahaan. Sistem pengendalian manajemen yang dibentuk untuk menjamin kepentingan pihak pemegang saham dan pihak lainnya terkenal dengan sebutan tata kelola perusahaan (Swami \& Latrini, 2013).

Komite audit tidak luput dari bagian tata kelola perusahaan yang berperan penting, Pernyataan ini dapat dilihat melalui adanya peraturan Otoritas Jasa Keuangan (OJK) No. 55/POJK.04/2015 yang menentukan formasi dan tugas komite audit dalam bekerja. Komite audit dinilai dapat mengendalikan penerbitan laporan keuangan dengan waktu yang akurat karena komite audit secara langsung menjalankan fungsi pengawasan terhadap partisipasi auditor eksternal dan manajemen dalam proses publikasi laporan keuangan (Hastuti \& Meiranto, 2017).

Semua perusahaan terbuka yang tercatat di Bursa Efek Indonesia (BEI) harus menaati kewajiban untuk mengumumkan laporan keuangan auditan pada lembaga Otoritas Jasa Keuangan (OJK) dimana ketentuan mengenai batas masa penerbitan laporan keuangan telah tertata di peraturan No. X.K.2 yakni 90 hari atau paling lambat tiga bulan setelah akhir tahun periode. Namun, walaupun ketentuan pemerintah sudah ditetapkan secara tertulis, masih ada kejadian konkret terkait perusahaan-perusahaan terbuka yang melebihi batas hari publikasi laporan keuangan yang muncul di pertengahan tahun 2018 dimana BEI mengumumkan secara tertulis bahwa terdapat 10 perusahaan yang belum melakukan penerbitan laporan keuangan yang sudah diaudit auditor eksternal per 31 desember 2017 hingga tanggal 28 Juni 2018. Pemberian sanksi juga dilakukan oleh BEI bagi perusahaan tersebut yang tidak memenuhi kewajiban sesuai aturan yang berlaku.

Berkaitan dengan fenomena yang dibahas di atas, memunculkan gagasan penelitian bagi penulis bahwa efektivitas komite audit bisa menjadi salah satu penyebab masih terjadinya keterlambatan audit di perusahaan terbuka, sehingga pelaksanaan penelitian ini dinamakan dengan "Analisis Pengaruh Karakteristik Komite Audit terhadap Keterlambatan Audit pada Perusahaan yang Terdaftar di Bursa Efek Indonesia".

\section{KAJIAN LITERATUR}

Keterlambatan audit atau yang biasa dikenal sebagai audit delay dapat dimaksudkan sebagai jangka waktu yang dilewati sejak tanggal akhir penutupan tahun buku hingga tanggal laporan audit terriliskan ( $\mathrm{Ng} \&$ Tai, 1994). Menurut Davies dan Whittred (1980) dibagi menjadi 2 pengertian, yaitu lamanya waktu proses pelaporan keuangan dan adanya lintang masa waktu antara akhir tahun periode sampai hari dipublikasinya laporan keuangan. 
Abdulla (1996) mengusulkan, lebih singkatnya masa waktu terhitung dari akhir tahun buku hingga tanggal dimana penerbitan laporan keuangan telah dilakukan, mendatangkan lebih banyak keuntungan yang bisa didapatkan dari laporan keuangan. Nilai informasi laporan keuangan auditan tersebut diyakini ikut merosot seiring bertambahnya lama waktu penyampaian laporan keuangan karena menyebabkan para pengguna informasi akan memperoleh sumber informasi lain yang lebih berpotensial dan membutuhkan biaya lebih (Knechel \& Payne, 2001). Keterlambatan audit, juga dihubungkan dengan informasi yang diperoleh pasar untuk menetapkan harga sekuritas, dimana adanya keterlambatan pengumuman laba sering dikaitkan dengan pengembalian yang lebih rendah dibandingkan dengan pengumuman laba yang lebih awal (Chambers \& Penman, 1984).

\section{Model Penelitian Terdahulu}

Dyer dan Mchugh (1975) melakukan penelitian terhadap keterlambatan audit di Australia dengan menggunakan model penelitian dibawah ini.

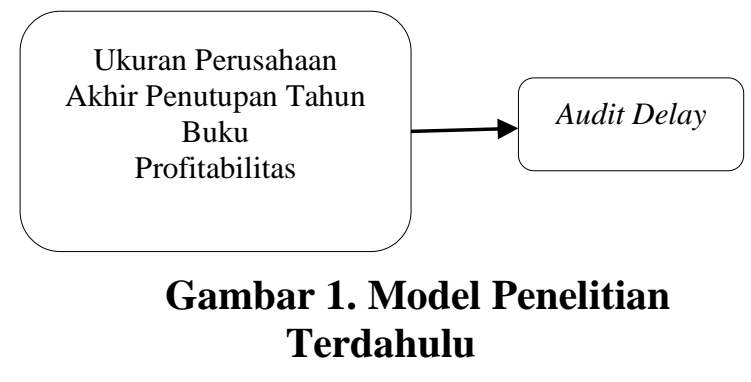

Carslaw dan Kaplan (1991) melakukan penelitian pada variabel dependen yang serupa di New Zealand dengan menambahkan beberapa variabel lainnya. Sampel penelitian yang digunakan berjumlah 245 perusahaan pada tahun 1987 dan 206 perusahaan pada tahun 1988. Dengan demikian, sampel tahun 1987 dan tahun 1988 mewakili 93\% dan 86\% dari total perusahaan yang tercatat di New Zealand Stock Exchange. Berikut merupakan model penelitiannya.

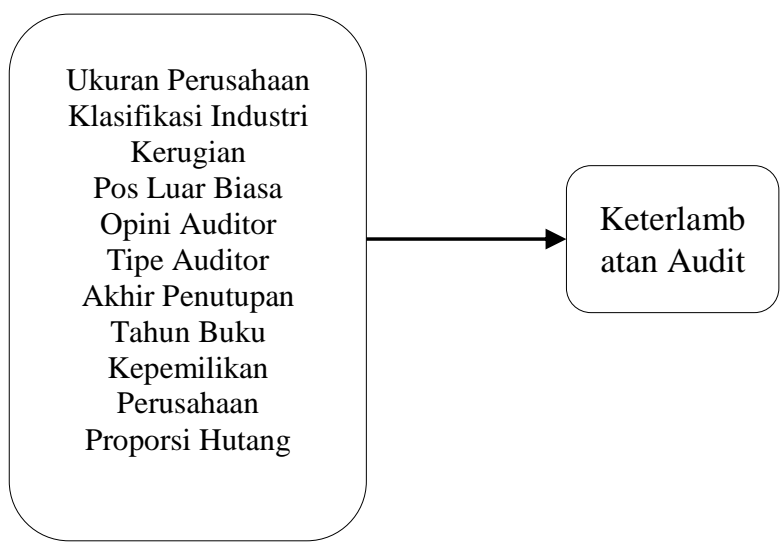

\section{Gambar 2. Model Penelitian Terdahulu}

Kajian penelitian mengenai unsur yang menyebabkan keterlambatan audit telah banyak dilaksanakan pada tahuntahun sebelumnya, hanya saja terdapat penggunaan variabel independen yang beragam dan berbeda oleh para peneliti. Ashton et al. (1989) dalam penelitiannya menggunakan variabel ukuran perusahaan. Variabel ini juga diteliti oleh OwusuAnsah (2000), Ika dan Ghazali (2012), Dibia dan Onwuchekwa (2013).

\section{Pengaruh Keahlian Keuangan Komite Audit terhadap Keterlambatan Audit \\ DeZoort dan Salterio (2001)} menuturkan, seorang tokoh komite audit lebih baik mempunyai pengetahuan maupun pengalaman sebelumnya dalam memeriksa kegiatan pelaporan keuangan karena lebih bisa memberikan penilaian yang lebih ahli, dimana bisa mencegah dan mendeteksi kemungkinan kesalahsajian yang material (Wardhani \& Raharja, 2013). Dengan kehadiran paling kurang satu tokoh ahli keuangan, khususnya akuntansi dalam struktur komite audit bisa meningkatkan kinerja dalam mengawasi jalannya pelaporan keuangan, yang demikian berdampak pada pencapaian laporan keuangan yang berprestasi baik ataupun berkualitas, termasuk 
ketepatwaktuan penerbitan laporan (Nugroho \& Rahadian, 2013).

\section{Pengaruh Independensi Komite Audit terhadap Keterlambatan Audit}

Hashim dan Rahman (2011) menambahkan, independensi komite audit berkaitan dengan teori agensi, dimana semakin tingginya proporsi anggota independen dalam komite audit, dapat meningkatkan kualitas terhadap pengawasan pengungkapan laporan keuangan sehingga bisa mengurangi ketidaksinambungan informasi. Dengan demikian, kemandirian ataupun independensinya tokoh komite audit lebih bisa diandalkan oleh pemegang saham dibandingkan dengan anggota yang non independen. Pendapat tersebut terbukti dengan penelitiannya dimana independensi tokoh komite audit ditemukan bisa mengurangi keterlambatan laporan audit.

\section{Pengaruh Pertemuan Komite Audit terhadap Keterlambatan Audit}

Perlu adanya sebuah rapat atau perkumpulan bagi tokoh komite audit sebagai forum kebutuhan penilaian dalam meyakinkan kualitas laporan keuangan yang akan disampaikan, dimana dalam pertemuan yang diadakan menjadi kesempatan dalam pencarian solusi atas munculnya masalah ataupun pemberian saran yang diharapkan bisa mendorong ketepatwaktuan penerbitan laporan (Akbar \& Kiswara, 2014).

\section{Pengaruh Piagam Komite Audit terhadap Keterlambatan Audit}

DeZoort et al. (2002) juga menambahkan, sebuah piagam sangat diperlukan karena memberikan bantuan kepada komite audit untuk berfokus atau konsentrasi terhadap pekerjaan mereka yang spesifik, serta mempermudahkan pihak yang berkepentingan dalam melakukan penilaian terhadap peran dan tanggungjawab komite audit. Oleh karena itu, kemunculan pedoman diharapkan dapat meningkatkan pekerjaan komite audit yang lebih efektif lagi, dimana bisa berujung pada ketepatwaktuan penyampaian laporan keuangan (Ika \& Ghazali, 2012).

\section{Pengaruh Profitabilitas terhadap Keterlambatan Audit}

Perusahaan yang sedang dalam keadaaan untung cenderung melakukan deklarasi laporan keuangan yang lebih cepat, namun kurang ingin menyampaikan kerugian dengan kecepatan waktu yang sama (Iyoha, 2012). Hal ini disebabkan karena perusahaan yang sedang mengalami kerugian mungkin menghendaki auditor untuk mulai merencanakan pelaksanaan audit pada tanggal yang lebih lama, yang mana akan memperpanjang penyelesaian laporan audit (Carslaw \& Kaplan, 1991) ataupun kemungkinan lainnya yakni manajemen perusahaan membutuhkan kelonggaran waktu untuk mengkaji ulang dan membuktikan pernyataan jika profitabilitas perusahaan dalam keadaan buruk (Daoud et al., 2014).

\section{Pengaruh Ukuran Perusahaan terhadap Keterlambatan Audit}

Ungkapan penelitian oleh Akbar dan Kiswara (2014) dengan hasil positif yang signifikan dimana terbuktinya ukuran perusahaan dalam skala besar yang diukur dengan logaritma total aset tertekan lebih kuat oleh publik dan para investor sehingga menjadi suatu dorongan untuk melakukan penyampaian laporan audit yang lebih awal.

\section{Pengaruh Konsentrasi Kepemilikan terhadap Keterlambatan Audit \\ Menurut Wardhana (2014), ada 2} bentuk konsentrasi kepemilikan saham dalam perusahaan, dimana pembagian konsentrasi ada yang bersifat padu dan ada yang bersifat menyebar. Perbedaan yang mencolok diantara kedua sifat tersebut, yakni pada pihak yang menguasai saham 
dimana para pemilik konsentrasi saham yang menyebar merupakan pihak yang mempunyai sedikit saham dalam perusahaan atau dikenal dengan sebutan kaum minoritas, sedangkan pemilik konsentrasi saham yang padu ialah kaum mayoritas yang karena kepemilikannya kuat sehingga pihak ini bisa mengatur pergerakan manajemen dalam perusahaan, seperti penuntutan kepada pihak manajemen untuk tidak menunda penyampaian laporan (Swami \& Latrini, 2013).

\section{Pengaruh Pergantian Auditor terhadap Keterlambatan Audit}

Auditor yang baru perlu mengadakan pertemuan atau berkenalan untuk berkomunikasi dengan auditor sebelumnya supaya bisa memahami alasan pemberhentian kerja yang dilakukan klien terhadap auditor lama, dan juga membicarakan sekilas mengenai gambaran perusahaan klien yang akan diteruskan auditor baru sehingga pada saat dimulai penugasan, auditor baru akan lebih mudah menyiapkan susunan perencanaan audit yang sesuai dengan klien (Arens, 2011). Hal demikianlah yang menyebabkan adanya pergantian auditor baru bisa mengakibatkan keterlambatan audit menjadi tinggi (Tambunan, 2014).

\section{Pengaruh Opini Audit terhadap Keterlambatan Audit}

Craswell, Francis, dan Taylor (1995) menyebutkan bahwa opini wajar dengan pengecualian dilihat sebagai kabar tidak baik dan memperlambat proses audit, dimana perusahaan yang tidak menerima unqualified opinion dinilai keterlambatan audit yang terjadi akan lebih tinggi daripada perusahaan yang menerima unqualified opinion.

\section{Pengaruh Koneksi Politik terhadap Keterlambatan Audit}

Chaney et al. (2011) berargumen, perusahaan yang terkoneksi politik akan mencoba menekan keterlambatan audit. Hal ini berkaitan dengan signalling theory, dimana kegiatan pengauditan yang lebih awal terselesaikan menandai suatu signal kepada publik bahwa kualitas laporan keuangan perusahaan tersebut wajar saja sehingga tambahan waktu untuk pengauditan tidak diperlukan auditor eksternal.

\section{Pengaruh Auditor Spesialis Industri terhadap Keterlambatan Audit}

Pengalaman yang banyak bagi seorang auditor khusus akan mudah mendapati kekeliruan dan juga lebih bisa memahami ciri dan sifat perusahaan dalam industri terkait secara spesifik dan menyeluruh, sehingga penyelesaian audit akan lebih awal terpenuhi (Owhoso, Messier, \& Lynch, 2002).

\section{Perumusan Hipotesis}

Sehubungan dengan ulasan yang sebelumnya dipaparkan, maka perumusan dugaan sementara penelitian seperti berikut:

$\mathrm{H}_{1}$ : Keahlian keuangan komite audit membawa pengaruh negatif yang signifikan pada keterlambatan audit.

$\mathrm{H}_{2}$ : Independensi komite audit membawa pengaruh negatif yang signifikan pada keterlambatan audit.

$\mathrm{H}_{3}$ : Ukuran komite audit membawa pengaruh negatif yang signifikan pada keterlambatan audit.

$\mathrm{H}_{4}$ : Pertemuan komite audit membawa pengaruh negatif yang signifikan pada keterlambatan audit.

$\mathrm{H}_{5}$ : Piagam komite audit membawa pengaruh negatif yang signifikan pada keterlambatan audit.

$\mathrm{H}_{6}$ : Profitabilitas membawa pengaruh negatif yang signifikan pada keterlambatan audit.

$\mathrm{H}_{7}$ : Ukuran perusahaan membawa pengaruh negatif yang signifikan pada keterlambatan audit. 
$\mathrm{H}_{8}$ : Konsentrasi kepemilikan membawa pengaruh positif yang signifikan pada keterlambatan audit.

$\mathrm{H}_{9}$ : Pergantian auditor membawa pengaruh positif yang signifikan pada keterlambatan audit.

$\mathrm{H}_{10}$ : Opini audit membawa pengaruh positif yang signifikan pada keterlambatan audit.

$\mathrm{H}_{11}$ : Koneksi politik membawa pengaruh positif yang signifikan pada keterlambatan audit.

$\mathrm{H}_{12}$ : Auditor spesialis industri membawa pengaruh negatif yang signifikan pada keterlambatan audit.

\section{METODE PENELITIAN}

Sumber berupa angka dimanfaatkan dalam pengukuran seluruh variabel dalam kajian penelitian ini, dimana penelitian ini bernama penelitian kuantitatif. Menurut Indriantoro dan Supomo (2009:23), klasifikasi penelitian yang dinilai dari unsur maksud dan visi, penelitian ini termasuk penelitian dasar dimana hanya mencarikan solusi masalah melalui pengkajian teori. Penelitian ini juga termasuk penelitian kausal-komparatif jika diamati dari aspek karakteristik permasalahan penelitian, yang berarti semua variabel satu sama lainnya mendatangkan relasi penyebab kemunculan dan akibat kemunculan (Indriantoro \& Supomo, 2009:27).

\section{Model Penelitian}

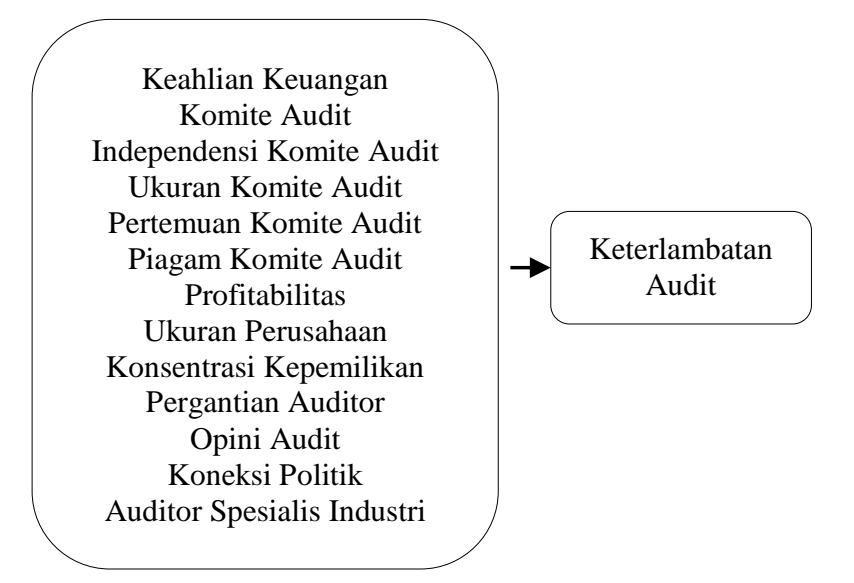

Gambar 3. Model Penelitian

\section{Variabel Dependen}

Keterlambatan Audit (ADL)

Baldacchino et al. (2016) mengemukakan, laporan tahunan hanya akan dideklarasikan setelah seorang auditor eksternal sudah memberi penilaian yang berbentuk opini audit pada penemuan fakta mengenai kewajaran nilai yang terkandung dalam pernyataan laporan keuangan. Namun, akan selalu ada sebuah lintang jarak diantara akhir tahun keuangan dan tanggal dimana informasi yang telah selesai diaudit sudah terpublikasikan. Keterjadian jarak yang muncul dimaksudkan sebagai keterlambatan audit yakni variabel dependen yang diujikan dalam penelitian ini, yang dapat diukur dengan jumlah hari yang terlewatkan dari tanggal akhir tahun keuangan hingga tanggal hari dimana seorang auditor independen telah menandatangani laporan audit yang sudah diselesaikan.

\section{Variabel Independen \\ Keahlian Keuangan (ACFE)}

Struktur keanggotaan atau tokoh komite audit berperan atau berpartisipasi secara langsung dalam kegiatan proses pembuatan laporan keuangan, dimana suatu kelebihan yang dimiliki komite audit mempermudah kegiatan pemeriksaan yang berlangsung. Kelebihan yang dimaksudkan yakni pendidikan ataupun ilmu akuntansi maupun keuangan yang dimiliki menjadikan tokoh komite audit jeli terhadap nilai-nilai angka yang terurai pada laporan sehingga tugas pengawasan menjadi efektif, sebagaimana bisa berdampak pada pengurangan keterlambatan audit (Abernathy et al., 2014).

Keahlian keuangan $=$ proporsi tokoh komite audit yang berpendidikan jurusan keuangan atau akuntansi dibagi pada total keseluruhan tokoh komite audit. 


\section{Independensi Komite Audit (ACI)}

Independensi komite audit bekerja dengan sudut pandang atau posisi yang tidak memihak pada siapapun, sehingga berkontribusi dalam mewujudkan penyampaian laporan yang berkualitas dan tidak menunda waktu (Yadirichukwu \& Ebimobowei, 2013).

Independensi komite audit $=$ proporsi tokoh komite audit yang independen dibagi pada jumlah seluruh tokoh komite audit.

\section{Komite Audit (ACS)}

Kefektifan pekerjaan komite audit akan terwujud bila terdapat sumber daya unggul atau yang tidak lain merupakan tokoh pekerja dalam komite audit. Keanggotaan yang banyak dinilai dapat mewujudkan efektivitas komite audit sehingga dapat menyelesaikan permasalahan dan mempengaruhi kualitas laporan keuangan serta mencegah keterlambatan audit. Jumlah tokoh atau sumber daya manusia dalam sebuah struktur komite audit diperlakukan sebagai indikator variabel ukuran komite audit (Nelson \& Shukeri, 2011).

Komite Audit $=$ Jumlah tokoh atau sumber daya manusia dalam sebuah komite audit.

\section{Pertemuan Komite Audit (ACM)}

Frekuensi pertemuan atau rapat yang diadakan komite audit berdampak pada semakin cepat penyelesaian laporan auditan karena forum rapat merupakan tempat berdiskusi untuk mencari solusi atas masalah yang timbul (Nugroho \& Rahadian, 2013).

Pertemuan komite audit $=$ Jumlah perkumpulan atau pertemuan yang diselenggarakan oleh komite audit selama setahun penuh atau satu periode keuangan.

\section{Piagam Komite Audit (ACC)}

Jangkauan tanggungjawab komite audit yang tertera dalam piagam berguna mengarahkan komite audit supaya lebih spesifik melaksanakan tugas pengawasan (Bédard, Chtourou, \& Courteau, 2004).

Piagam komite audit $=$ bernilai 1 ketika perusahaan mengadopsi sebuah piagam komite audit, dan bernilai 0 jika perusahan tidak mengadopsinya

\section{Profitabilitas (ROA)}

Perusahaan diamati lebih sering menyampaikan laporan keuangannya dengan segera atau cepat jika profitabilitas perusahaan tinggi dan menunda penyampaian laporan keuangan jika profitabilitas perusahaan dalam keadaan rendah (Okalesa, 2018).

Profitabilitas = laba bersih dibagi dengan jumlah aset perusahaan.

\section{Ukuran Perusahaan (FS)}

Suatu organisasi atau perusahaan yang berukuran besar tentunya mempunyai sumber daya yang juga besar, yang mana mendorong pelaksanaan audit menjadi lebih ringan dan lancar (Sutikno \& Hadiprajitno, 2015).

Ukuran perusahaan $=$ natural log dari jumlah penjualan suatu perusahaan (Oussii \& Taktak, 2018).

\section{Konsentrasi Kepemilikan (OWC)}

Pengumpulan data konsentrasi kepemilikan bisa didapatkan pada seksi modal saham atau ekuitas di catatan atas laporan keuangan konsolidasian perusahaan, dimana disana tercantum siapa saja pihak pemegang saham perusahaan dan masing-masing persentase kepemilikannya.

Konsentrasi kepemilikan $=$ jumlah seluruh persentase kepemilikan modal saham yang lebih dari 5\% (Basuony, Mohamed, Hussain, \& Marie, 2016).

\section{Pergantian Auditor (ADC)}

Pergantian auditor terjadi karena telah usainya perjanjian atau kesepakatan kerja antara auditor eksternal dengan klien atau perusahaan bersangkutan.

Pergantian auditor = bernilai 1 berlaku bagi perusahaan yang menukar auditor 
baru pada periode berjalan dan pemberian nilai 0 berlaku untuk sebaliknya (Oussii \& Taktak, 2018).

\section{Opini Audit (QUOP)}

Pendapat atau opini auditor sebagai kesimpulan pernyataan yang profesional dari seorang auditor independen yang telah menjalani pemeriksaan atau penemuan fakta yang terurai pada laporan keuangan perusahaan (Widosari, 2012).

Opini auditor = bernilai 1 kalau auditor eksternal menyatakan qualified opinion, dan pemberian nilai berupa 0 untuk pernyataan selain qualified opinion (Oussii \& Taktak, 2018).

\section{Koneksi Politik (POLC)}

Definisi koneksi politik dilihat dari segi apakah pemerintah mempunyai kepemilikan terhadap perusahaan tersebut (Andhikari, Chek, \& Hao, 2006).

Koneksi politik $=$ dinilai 1 jika minimal satu dari pemegang saham atau manajemen perusahaan termasuk seseorang dari bagian tokoh parlemen, menteri, atau politisi dan tokoh partai politik, dan penilaian 0 untuk pernyataan sebaliknya (Oussii \& Taktak, 2018).

\section{Auditor Specialis Industri (SIA)}

Pengalaman dan ilmu mendalam yang melekat pada auditor spesialis industri memunculkan pandangan dan harapan kepada auditor tersebut untuk bisa mengurangi terjadinya keterlambatan audit (Rustiarini \& Sugiarti, 2013). Dianggap spesialis jika auditor KAP telah melaksanakan proses audit sebesar $10 \%$ dari jumlah perusahaan yang termasuk dalam industri terkait.

Auditor specialis industri $=$ pemberian nilai 1 ketika pengauditan perusahaan dilaksanakan oleh auditor spesialis industri, dan pemberian nilai 0 ketika pengauditan perusahaan dilakukan oleh auditor nonspesialis industri (Oussii \& Taktak, 2018).

\section{HASIL DAN PEMBAHASAN}

\section{Statistika Deskriptif}

Tertera pada tabel 1 yakni rangkuman langkah pemilihan sampel yang terlaksanakan. Hingga tahun 2019 saat ini, perusahaan yang terdaftar di BEI berjumlah 649. Kemudian, sebanyak 203 perusahaan dikeluarkan dari penyeleksian sampel dengan alasan tidak terpenuhinya syarat atau kriteria yang sudah sejak awal diputuskan dalam penelitian. Pengumpulan olahan data diambil selama 5 tahun dari tahun 2014-2018, dimana diperoleh 2.230 data yang diantaranya terdapat 510 data outlier. Sehingga, akhir total data yang disisakan dan dapat diteliti berjumlah 1.720 data.

Tabel 1

Hasil Langkah Pemilihan Sampel Penelitian

\begin{tabular}{lc}
\hline \multicolumn{1}{c}{ Keterangan } & Jumlah \\
\hline Perusahaan BEI 2019 & 649 perusahaan \\
Perusahaan tidak sesuai kriteria & (203 perusahaan) \\
\cline { 2 - 2 } Jumlah sampel & 446 perusahaan \\
Jumlah sampel selama 5 tahun & 2.230 data \\
Jumlah sampel outlier & (510 data) \\
Hasil akhir yang akan diuji & 1.720 data \\
\hline
\end{tabular}

Sumber: Data sekunder diolah (2019)

Diperlihatkan tabel 1 bahwa, keterlambatan audit memiliki nilai minimum 30 yang berarti laporan keuangan yang paling cepat dipublikasikan yaitu 30 hari oleh PT Bank Mandiri (Persero) Tbk. (BMRI) tahun 2016. Nilai maksimum yang menunjukkan angka 117 , dimana berarti pelaporan keuangan paling lambat terjadi pada PT Global Teleshop Tbk (GLOB) tahun 2016 dan PT Steady Safe Tbk (SAFE) tahun 2017 yaitu selama 117 hari. Sebagian besar perusahaan di BEI sudah mematuhi ketentuan OJK No. X.K.2 yang memberi batasan maksimal 90 hari dimana laporan keuangan auditan sudah harus terpublikasikan, yang ditandai dengan rata-rata hanya 79 hari yang diperlukan untuk selesai pengauditan laporan. Standar deviasi keterlambatan audit yang bernilai 9,55226, bernilai lebih 
rendah dari nilai rata-rata menegaskan bahwa data keterlambatan audit tidak bervariasi tinggi.

Nilai minimum pada keahlian keuangan komite audit yang menunjukkan angka 0 dikarenakan PT Indonesia Transport and Infrastructure Tbk. (IATA) tahun 2018 tidak memiliki tokoh komite audit yang berkeahlian keuangan. Nilai maksimum yang menunjukkan angka 1 berarti seluruh anggota komite audit merupakan ahli keuangan. Perusahaan PT Bank Tabungan Negara Tbk (Persero) atau BBTN tahun 2017 dan PT Bank Mandiri (Persero) Tbk atau BMRI pada tahun 2014 dan 2016 mempunyai anggota komite audit yang berkeahlian keuangan paling kuat yakni 6 tokoh. Rata-rata perusahaan memiliki 2 tokoh dalam komite audit yang merupakan ahli keuangan, dimana hal ini berarti perusahaan mematuhi ketentuan OJK No. 55/POJK.04/2015 yang mengharuskan setidaknya terdapat 1 anggota dalam komite audit yang berkeahlian dalam keuangan. Standar deviasi sebesar $28 \%$ dari nilai rata-rata berarti data keahlian keuangan komite audit hampir bervariatif, dimana standar deviasi yang mencapai lebih dari $33 \%$ nilai rata-ratanya mengindikasi tingginya variasi data terkait (Santoso, 2012).

Regulasi OJK No. 55/POJK.04/2015 juga mewajibkan anggota komite audit harus independen dan komite audit harus diketuai oleh seorang tokoh komisaris yang juga merupakan pihak independen. Nilai minimum 0,67 yang tertera menunjuk pada perusahaan BMRI tahun 2016 dimana terdapat 4 anggota independen dari total komite auditnya yang berjumlahkan 6 anggota. Nilai maksimum yang memperlihatkan angka 1 berarti seluruh anggota komite audit sebagian besar perusahaan merupakan pihak eksternal. Data independensi komite audit sangat tidak menyebar, dimana ditunjukkan dengan nilai standar deviasi 0,02672 yang jauh lebih lemah dari nilai rata-rata 0,9971 .
PT Citra Marga Nusaphala Persada Tbk (CMNP) tahun 2016 dan PT FKS Multi Agro Tbk (FISH) tahun 2014 memiliki tokoh komite audit yang paling sedikit yakni 1 orang yang diuraikan oleh nilai minimum pada tabel 2. Sedangkan, BBTN dan BCIC keduanya bersama-sama di tahun 2016 memiliki keanggotaan komite audit terbanyak yang diwakili nilai maksimum sebesar 7 orang. Angka 3 pada nilai rata-rata menjelaskan perusahaan sudah menepati regulasi OJK No. 55/POJK.04/2015 yang mana dalam isi regulasi disebutkan sebuah komite audit dalam perusahaan paling tidak harus berisikan 3 orang. Standar deviasi dengan angka 0,48822 yang tidak lebih tinggi dari nilai rata-rata mengartikan ukuran komite audit kurang menyebar.

Rata-rata komite audit pada perusahaan di BEI melaksanakan perkumpulan sebanyak 6 kali selama setahun, dimana nilai rata-rata tersebut membuktikan regulasi OJK No. 55/POJK.04/2015 yang mengatur paling sedikit komite audit harus menyelenggarakan 1 kali pertemuan setiap kuartal atau dengan kata lain 4 kali pertemuan dalam setahun sudah ditaati sebagian besar perusahaan. Adanya PT AirAsia Indonesia Tbk (CMPP) pada tahun 2017 yang belum sempat melakukan rapat atau perkumpulan menyebabkan munculnya nilai nol pada tabel 2 . Sedangkan pertemuan terbanyak dengan jumlah 75 kali rapat yang diadakan terjadi pada PT Pembangunan Jaya Ancol Tbk (PJAA) tahun 2017. Tingginya variasi pertemuan komite audit ditandai dengan nilai standar deviasinya yang $97 \%$ dari nilai rata-ratanya.

Pengukuran profitabilitas perusahaan dengan rumus ROA atau return on asset yang menerangkan 0,0228756 nilai rataratanya mengartikan kemampuan perusahaan untuk memperoleh keuntungan 0,0228756 rupiah dari 1 rupiah aktiva atau aset yang dikuasai. Angka 0,92100 pada nilai maksimum merupakan keuntungan 
laba bersih yang dihasilkan MERK tahun 2018 senilai Rp 1.163.324.165.000,- dari total aset senilai Rp 1.263.113.689.000,-Sedangkan kerugian senilai $\mathrm{Rp}$ 87.813.208.550.000,- dari total aset senilai Rp 74.599.266.089.000,- yang dialami GLOB pada tahun 2016 menyebabkan kemunculan nilai minimum profitabilitas yakni -1,58370. Standar deviasi yang ditunjukkan yakni 0,10927484 melebihi nilai rata-rata 0,0228756 berarti data profitabilitas perusahaan cukup menyebar.

Pengukuran variabel ukuran perusahaan ini berdasarkan total penjualan perusahaan yang di natural log kan. Angka nilai minimum yang menunjukkan nol disebabkan oleh PT Central Omega Resources Tbk (DKFT) yang tidak melakukan penjualan sepanjang tahun 2014. Nilai penjualan perusahaan tertinggi jatuh pada PT Astra International Tbk (ASII) tahun 2018 sebesar Rp 239.205.000.000.000,-. Rata-rata ukuran perusahaan dengan nilai 27,7599151 yang jauh lebih besar dari nilai standar deviasi yang menunjukkan 2,212655038 mengartikan bahwa variasi variabel ukuran perusahaan sangat rendah.

Nilai rata-rata yang menguraikan 0,7201235 pada variabel konsentrasi kepemilikan memberi pengartian bahwa saham perusahaan di BEI rata-rata dikuasai oleh kaum mayoritas. Nilai minimum sebesar 0,06610 membuktikan bahwa kepemilikan saham pada perusahaan sangat tersebar, yang terjadi pada PT Bakrie Sumatera Plantations Tbk (UNSP) tahun 2014 dan 2015. Sedangkan pemegang saham di perusahaan PT Bank Brisyariah (BRIS) pada tahun 2014 dan 2015 menguasai 99,97\% saham di BRIS, yang diwakili nilai maksimum dengan angka 0,99970. Data konsentrasi kepemilikan perusahaan kurang menyebar dikarenakan nilai standar deviasi kurang dari nilai rata-rata, dimana standar deviasi bernilai 0,17356013 dan rata-rata bernilai 0,7201235 .
Tabel 2 Hasil Statistika Deskriptif

\begin{tabular}{|c|c|c|c|c|c|}
\hline \multirow{2}{*}{ Var } & \multicolumn{5}{|c|}{ Statistik Deskriptif } \\
\hline & $\mathbf{N}$ & Min & Max & Mean & S.Dev \\
\hline $\mathrm{ADL}$ & 1720 & $\begin{array}{l}30, \\
00\end{array}$ & $\begin{array}{c}117, \\
00\end{array}$ & 79,4285 & 9,55226 \\
\hline ACFE & 1720 & 0,00 & 1,00 & 0,8018 & 0,22860 \\
\hline ACI & 1720 & 0,67 & 1,00 & 0,9971 & 0,02672 \\
\hline ACS & 1720 & 1,00 & 7,00 & 3,0878 & 0,48822 \\
\hline $\mathrm{ACM}$ & 1720 & 0,00 & 75,00 & 6,7297 & 6,56304 \\
\hline ROA & 1720 & $\begin{array}{c}- \\
1,58 \\
370\end{array}$ & $\begin{array}{c}0,921 \\
00\end{array}$ & $\begin{array}{c}0,02287 \\
56\end{array}$ & $\begin{array}{c}0,109274 \\
84\end{array}$ \\
\hline FS & 1720 & $\begin{array}{c}0,00 \\
000\end{array}$ & $\begin{array}{c}33,10 \\
834\end{array}$ & $\begin{array}{c}27,7599 \\
151\end{array}$ & $\begin{array}{c}2,216550 \\
38\end{array}$ \\
\hline OWC & 1720 & $\begin{array}{c}0,06 \\
610\end{array}$ & $\begin{array}{c}0,999 \\
70\end{array}$ & $\begin{array}{c}0,72012 \\
35\end{array}$ & $\begin{array}{c}0,173560 \\
13\end{array}$ \\
\hline
\end{tabular}

Sumber: Data sekunder diolah (2019)

Berdasarkan tampilan tabel 2, dapat ditarik kesimpulan sebagian besar perusahaan telah mengadopsi piagam komite audit. Hal ini terbukti dimana terdapat 1.412 perusahaan dalam sampel telah memiliki piagam komite audit dengan perwakilan persentase sebesar $82,1 \%$ dan 308 perusahaan masih belum mengadopsi piagam komite audit dengan perwakilan persentase sebesar $17,9 \%$.

Tabel 3

Statistika Deskriptif Piagam Komite Audit

\begin{tabular}{|c|c|c|c|c|}
\hline & Fre. & Per. & Per.Valid & $\begin{array}{c}\text { Per. } \\
\text { Kumulatif }\end{array}$ \\
\hline $\begin{array}{l}\text { No } \\
\text { Charter }\end{array}$ & 308 & 17,9 & 17,9 & 17,9 \\
\hline $\begin{array}{l}\text { Has } \\
\text { Charter }\end{array}$ & 1.412 & 82,1 & 82,1 & 100 \\
\hline Total & 1.720 & 100 & 100 & \\
\hline
\end{tabular}

Sumber: Data Sekunder diolah (2019)

Tabel 3 memberitahukan bahwa terdapat 229 perusahaan mengganti auditor baru untuk pelaksanaan audit yang diwakili persentase senilai $13,3 \%$ dan 1.491 perusahaan dengan perwakilan persentase senilai $86,7 \%$ tidak mengganti auditor baru, dimana mengartikan terdapat sebagian kecil perusahaan dalam sampel yang mengganti dan mempekerjakan auditor baru sepanjang tahun keuangan. 
Tabel 4

Statistika Deskriptif Pergantian Auditor

\begin{tabular}{lrrrr}
\hline & Fre. & Per. & Per.Valid & $\begin{array}{c}\text { Per. } \\
\text { Kumulatif }\end{array}$ \\
\hline $\begin{array}{l}\text { Unchange } \\
\text { Auditor }\end{array}$ & 1.491 & 86,7 & 86,7 & 86,7 \\
$\begin{array}{l}\text { Changed } \\
\text { Auditor }\end{array}$ & 229 & 13,3 & 13.3 & 100 \\
Total & 1.720 & 100 & 100 & \\
\hline
\end{tabular}

Sumber: Data Sekunder diolah (2019)

Sesuai data pada tabel 4, diketahui bahwa perusahaan yang tergolong memperoleh opini selain qualified opinion sebanyak 1,700 perusahaan yang diwakili persentase $98,8 \%$ dan hanya terdapat 20 perusahaan yang menerima qualified opinion yang diwakilkan dengan persentase sebesar 1,2\%. Hal ini menunjukkan hanya sedikit perusahaan yang mendapatkan qualified opinion dari auditor eksternal.

Tabel 5

Statistika Deskriptif Opini Audit

\begin{tabular}{lrrrr}
\hline & \multicolumn{1}{c}{ Fre. } & \multicolumn{1}{c}{ Per. } & Per.Valid & $\begin{array}{c}\text { Per. } \\
\text { Kumulatif }\end{array}$ \\
\hline Others & 1.700 & 98,8 & 98,8 & 98,8 \\
$\begin{array}{l}\text { Opinion } \\
\text { Qualified }\end{array}$ & 20 & 1,2 & 1,2 & 100 \\
$\begin{array}{l}\text { Opinion } \\
\text { Total }\end{array}$ & 1.720 & 100 & 100 & \\
\hline
\end{tabular}

Sumber: Data Sekunder diolah (2019)

Bisa disimpulkan bahwa terdapat 103 perusahaan dengan persentase $6 \%$ yang terkoneksi politik yang ditunjukkan pada tabel 5 dan ada 1.617 perusahaan yang tidak terkoneksi politik dengan persentase 94\%, dimana berarti hanya sedikit perusahaan dalam sampel yang memiliki hubungan politik.

\section{Tabel 6}

Statistika Deskriptif Koneksi Politik

\begin{tabular}{lrrrr}
\hline \multicolumn{5}{c}{ Statistika Deskriptif Koneksi Politik } \\
\hline $\begin{array}{l}\text { No } \\
\begin{array}{l}\text { Political } \\
\text { Connected }\end{array}\end{array}$ & 1.617 & 94 & 94 & 94 \\
$\begin{array}{l}\text { Political } \\
\text { Connected }\end{array}$ & 103 & 6 & 6 & 100 \\
Total & 1.720 & 100 & 100 & \\
\hline
\end{tabular}

Sumber: Data Sekunder diolah (2019)

Persentase nilai $51,6 \%$ pada tabel 7 menerangkan bahwa terdapat 888 perusahaan yang mempekerjakan seorang auditor berspesialis dalam industri terkait untuk pengauditan, sedangkan persentase nilai 48,4\% menunjukkan 832 perusahaan diaudit oleh auditor yang nonspesialis dalam bidang industri. Hasil statistika deskriptif ini menyimpulkan lebih dari setengah perusahaan yang dimasukkan dalam sampel penelitian mempekerjakan auditor spesialis untuk pengauditan laporan keuangan perusahaan.

Tabel 7

Statistika Deskriptif Auditor Spesialis Industri

\begin{tabular}{lcccr}
\hline & Fre. & Per. & Per.Valid & $\begin{array}{c}\text { Per. } \\
\text { Kumulatif }\end{array}$ \\
\hline $\begin{array}{l}\text { Non- } \\
\text { specialist }\end{array}$ & 832 & 48,4 & 48,4 & 48,4 \\
$\begin{array}{l}\text { Industry } \\
\text { Auditor } \\
\text { Specialist }\end{array}$ & & & & \\
$\begin{array}{l}\text { Industry } \\
\text { Auditor }\end{array}$ & 888 & 51,6 & 51,6 & 100 \\
Total & 1.720 & 100 & 100 & \\
\hline
\end{tabular}

Sumber: Data Sekunder diolah (2019)

\section{Uji Regresi Panel}

Penentuan model diantara PLS dan FEM didapatkan dari hasil uji Chow dengan memperhatikan angka pada nilai probabilitas yang muncul di Cross-section Chi-Square. Nilai probabilitas yang muncul di tabel 8 merupakan 0,0000 yang pada kenyataanya lebih rendah dari 0,05 sehingga pengujian selanjutnya yakni uji Hausman perlu dilanjutkan dalam menentukan model yang paling benar.

Tabel 8 Hasil Uji Chow

\begin{tabular}{lccc}
\hline Effects Test & Statistic & d.f. & Prob. \\
\hline $\begin{array}{l}\text { Cross-section } \\
\text { Chi-square }\end{array}$ & 1551,240331 & 415 & 0,0000
\end{tabular}

Sumber: Data sekunder diolah (2019)

Penggunaan uji Hausman berlaku sebagai penentu model diantara FEM dan REM. Kemunculan angka nilai probabilitas uji Hausman pada Crosssection random di tabel 9 ini sebesar 0,0000 yang kurang dari 0,05 mengartikan bahwa model yang paling sesuai digunakan dalam penelitian ini yakni FEM. 
Tabel 9 Hasil Uji Hausman

\begin{tabular}{lccc}
\hline $\begin{array}{l}\text { Test } \\
\text { Summary }\end{array}$ & $\begin{array}{c}\text { Chi-Sq. } \\
\text { Statistic }\end{array}$ & Chi-Sq. d.f. & Prob. \\
\hline $\begin{array}{l}\text { Cross-section } \\
\text { random }\end{array}$ & 53,675404 & 12 & 0,0000 \\
\hline
\end{tabular}

Sumber: Data sekunder diolah (2019)

Uji Hipotesis

Tabel 10 Hasil Uji F

\begin{tabular}{lc}
\hline Variabel Dependen & Prob. \\
\hline Keterlambatan Audit & 0,0000 \\
\hline
\end{tabular}

Sumber: Data sekunder diolah (2019)

Dapat diketahui mengenai apakah variabel bebas berpengaruh secara bersamaan atau simultan pada variabel terpengaruh melalui Uji F, dimana hasil uji ini dapat dikatakan signifikan dengan syarat nilai probabilitas tidak boleh lebih dari 0,05. Berlawanan, dimana akan disimpulkan tidak signifikan apabila nilai probabilitas yang keluar ternyata lebih tinggi dari 0,05. Hasil uji $\mathrm{F}$ ditampilkan pada tabel 10 .

Tabel 11 Hasil Uji $t$

\begin{tabular}{lcccc}
\hline \multicolumn{1}{c}{ Var } & Koefisien & t-Statistic & Prob. & Hasil \\
\hline ACFE & $-2,329920$ & $-1,630405$ & 0,1033 & Tidak Sig \\
ACI & 7,282161 & 0,469102 & 0,6391 & Tidak Sig \\
ACS & $-2,840440$ & $-5,128502$ & 0,0000 & Sig - \\
ACM & $-0,021986$ & $-0,320869$ & 0,7484 & Tidak Sig \\
ACC & 0,717440 & 0,951163 & 0,3417 & Tidak Sig \\
ROA & $-10,32467$ & $-5,230118$ & 0,0000 & Sig - \\
FS & $-0,480968$ & -2.843271 & 0,0045 & Sig - \\
OWC & 0,322115 & 0,138905 & 0,8895 & Tidak Sig \\
ADC & $-0,028814$ & $-0,058175$ & 0,9536 & Tidak Sig \\
QUOP & 6,429585 & 3,510096 & 0,0005 & Sig + \\
POLC & $-2,480312$ & $-1,384008$ & 0,1666 & Tidak Sig \\
SIA & 0,311523 & 0,338004 & 0,7354 & Tidak Sig \\
\hline Sumber: Data &
\end{tabular}

Sumber: Data sekunder diolah (2019)

Sesuai dengan hasil uji t yang telah diuraikan pada tabel 11, sehingga persamaan regresi panel yang bisa ditarik dari penelitian ini yakni:

$\mathrm{ADL}=-2,329920 \mathrm{ACFE}+7,282161 \mathrm{ACI}$
$-2,840440 \mathrm{ACS}-0,021986 \mathrm{ACM}+$
$0,717440 \mathrm{ACC}-10,32467 \mathrm{ROA}-$
$0,480968 \mathrm{FS}+0,322115 \mathrm{OWC}-$

0,028814ADC $+6,429585 \mathrm{QUOP}-$

$2,480312 \mathrm{POLC}+0,311523 \mathrm{SIA}+e$

\section{Analisis Pengaruh ACFE terhadap ADL}

Sebesar 0,1033 nilai signifikansi variabel keahlian keuangan komite audit memiliki arti tidak signifikan. Hasil yang tidak signifikan ini terjadi karena komite audit menaruh perhatian yang lebih pada keakuratan dan kredibilitas angka-angka akuntansi yang tertera daripada relevansi dari angka tersebut, karena reputasi komite audit secara signifikan lebih terancam pada kasus-kasus seperti manipulasi bilangan akuntansi daripada ketepatwaktuan pengungkapan (Salleh, Baatwah, \& Ahmad, 2017).

Kesimpulan ini selaras dengan bukti yang diungkapkan oleh Ghafran dan Yasmin (2017), Shukeri dan Islam (2012), Ismail, Mustapha, dan Ming (2012), dan Salleh et al. (2017). Hasil yang berlawanan dengan penelitian Rianti dan Sari (2014), Raweh, Kamardin, dan Malik (2019), Kusuma (2014), Handayani dan Yustikasari (2017), dan Akbar dan Kiswara (2014), yang mana membuktikan adanya hasil signifikan yang negatif. Sedangkan Yadirichukwu dan Ebimobowei (2013) dan Ozoanigbo, Orjinta, dan Ofor (2016) menemukan hasil signifikan yang positif.

\section{Analisis Pengaruh ACI terhadap ADL}

Komite audit yang independen ternyata tidak mampu membawa pengaruh pada penundaan penyelesaian audit, yang diwakilkan dengan nilai signifikansi variabel ini sebesar 0,6391. Penyebab munculnya hasil ini yakni pembentukan komite audit yang beranggotakan pihak independen hanya merupakan pemenuhan atas kewajiban yang diberlakukan dalam peraturan, dimana independensi tersebut tidak mengoptimalkan pekerjaan komite audit Abdullah (2007).

Kesamaan hasil juga diungkapkan dalam penelitian Purwati (2006), Susanti (2018), Anugrah dan Laksito (2017), 
Abdullah (2007), Widyaswari dan Suardana (2014), dan Oussii dan Taktak (2018). Penelitian Wardhani (2013), Wardhani dan Raharja (2013), dan Hashim dan Rahman (2011) menyanggah hasil ini karena mendapati adanya hubungan signifikan yang negatif, sedangkan bukti hubungan signifikan yang positif juga diterbitkan dalam penelitian Yadirichukwu dan Ebimobowei (2013) dan Ozoanigbo et al. (2016).

\section{Analisis Pengaruh ACS terhadap ADL}

Terbuktinya variabel ini diwakilkan nilai signifikansi yang menunjukkan 0,0000 dan nilai koefisien $-2,840440$ menyimpulkan hasil bahwa adanya dampak penting yang negatif dari ukuran komite audit pada keterlambatan audit. Menurut Mohamad-Nor, Shafie, dan Wan-Hussin (2010), struktur komite audit yang berjumlah banyak anggota bisa mendesak manajemen untuk menyelesaikan laporan lebih awal sehingga laporan audit juga bisa lebih awal disampaikan.

Kesimpulan penemuan ini rupanya konsisten dengan bukti oleh Apadore dan Noor (2013), Arifa (2013), Salleh et al. (2017), Nelson dan Shukeri (2011), dan Darsono (2017), akan tetapi bertolak belakang dengan bukti signifikan yang positif dimana ditemukan oleh Ilaboya dan Christian (2014) dan Raweh et al. (2019). Nugroho dan Rahadian (2013), Widyaswari dan Suardana (2014), Widosari (2012), Sultana, Singh, dan Van der Zahn (2015) dan Ahmed dan CheAhmad (2016) tidak mendapati bukti signifikan dari variabel ini.

\section{Analisis Pengaruh ACM terhadap ADL}

Variabel pertemuan komite audit yang diuraikan dengan nilai signifikansi sebesar 0,7484 berarti tidak signifikan. Hal ini dikarenakan kinerja komite audit tidak bisa hanya dilihat dari frekuensi perkumpulan atau pertemuan yang diadakan, namun sebaiknya dinilai dari kualitas hasil dari apa yang dibahas dalam pertemuan sehingga bisa memberti kontribusi yang berarti bagi perusahaan. Hasil tidak signifikan variabel ini ditunjang oleh penelitian Noeryanto (2015), Kusuma (2014), Hashim dan Rahman (2011), Dabor dan Mohammed (2015), Ismail et al. (2012), dan Sultana et al. (2015). Namun dibantah oleh hasil signifikan negatif dari Nugroho dan Rahadian (2013), Hastuti dan Meiranto (2017), Samaha dan Khlif (2017) dan hasil signifikan positif oleh Yunos (2017) dan Shukeri dan Islam (2012).

\section{Analisis Pengaruh ACC terhadap ADL}

Tidak ada penunjukan hubungan signifikan piagam komite audit pada keterlambatan audit yang diperlihatkan oleh nilai signikansi sebesar 0,3417. Piagam komite audit nyatanya tidak mampu mengurangi keterlambatan audit yang terjadi, hal ini dikarenakan peraturan yang berlaku mewajibkan perusahaan untuk mengadopsikan piagam, namun mengenai isi dalam piagam tidak begitu rinci sehingga piagam kurang optimal mendukung pekerjaan komite audit (Oussii \& Taktak, 2018). Kesimpulan hasil ini sejalan dengan hasil Akbar dan Kiswara (2014), Hastuti dan Meiranto (2017), Kusuma (2014), dan Oussii dan Taktak (2018).

\section{Analisis Pengaruh ROA terhadap ADL}

Profitabilitas terbukti mempunyai hubungan negatif yang signifikan pada keterlambatan audit dengan nilai signifikansi 0,0000 dan koefisien 10,32467. Profitabilitas perusahaan yang dalam kondisi bagus akan segera melakukan penerbitan laporan untuk bisa menarik lebih banyak investor dan sebaliknya akan menutupi kabar buruk dan memperlambat publikasian jika profitabilitas berkondisi jelek (Murdiawati, 2016).

Hasil signifikan negatif ini sesuai dengan hasil pengujian Carbaja dan 
Yadnyana (2015), Wijayanto (2016), Lestari (2010), Murdiawati (2016), Ocak dan Özden (2018), dan Efobi dan Okougbo (2014) dan bertolak belakang dengan hasil Dao dan Pham (2014), Okalesa (2018), dan Al-tahat (2015) yang membuktikan hasil profitabilitas justru memperlama keterlambatan audit. Penelitian Susanti (2018), Alkhatib dan Marji (2012), dan Sutapa dan Wirakusuma (2013) menyanggah kesimpulan hasil ini, dimana keempat peneliti ini tidak menemukan bukti signifikan.

\section{Analisis Pengaruh FS terhadap ADL}

Terbukti dengan nilai signifikansi 0,0045 dan nilai koefisien -0,480968, sehingga variabel ukuran perusahaan disimpulkan membawa pengaruh signifikan secara negatif pada keterlambatan audit. Perusahaan yang cukup besar biasanya lebih diawasi erat oleh publik, sehingga akan berusaha mengurangi penerbitan laporan yang telat, dimana salah satu caranya yakni memberi insentif yang lebih tinggi pada para pengelola perusahaan (Wijayanto, 2016). Kesimpulan hasil ini setara dengan hasil penelitian yang terlaksana oleh Sakka dan Jarboui (2015), Kartika (2009), AlGhanem dan Hegazy (2011), Swami dan Latrini (2013), dan Apriyana (2017), namun berlawanan arah dengan hasil Samaha dan Khlif (2017), Carbaja dan Yadnyana (2015), dan Sutapa dan Wirakusuma (2013). Di sisi lain, penelitian Mantik dan Sujana (2011), Murdiawati (2016) dan Iskandar dan Trisnawati (2010) tidak menemukan hasil yang signifikan pada variabel tersebut.

\section{Analisis Pengaruh OWC terhadap ADL}

Konsentrasi kepemilikan dengan nilai signifikansi sebesar 0,8895, dimana variabel ini tidak terbukti dapat mempengaruhi keterlambatan audit. Para kaum mayoritas dalam perusahaan tidak bisa hanya karena keinginan sepihak menuntut kualitas audit yang tinggi, namun lalai dalam mempertimbangkan hak kaum minoritas yang lebih menjunjung ketepatwaktuan tersedianya informasi. Penunjukan hasil tidak signifikan ini serupa dengan Afify (2009), Setiawan dan Nahumury (2014), Apadore dan Noor (2013), dan Khoufi dan Khoufi (2018) namun dibantah oleh penelitian Ettredge, Li, dan Sun (2005), dan Abdelsalam dan Street (2007) yang membuktikan adanya pengaruh signifikan dengan arah negatif, serta penelitian Basuony et al. (2016) dan Sakka dan Jarboui (2015) yang membuktikan konsentrasi kepemilikan membawa dampak signifikan secara positif.

\section{Analisis Pengaruh ADC terhadap ADL}

Nilai signifikansi yang diuraikan sebesar 0,9536 mengartikan tidak adanya pengaruh signifikan yang diharapkan. Variabel pergantian auditor tidak terbukti memberi dampak signifikan pada waktu penyelesaian audit, sebab penggantian seorang auditor baru diadakan jauh sebelum akhir periode keuangan, dimana sebelum melakukan penerimaan klien, auditor perlu melakukan pertimbangan dan pemahaman mengenai bisnis klien yang mana memakan waktu sekitar 3-6 bulan sebelum akhir periode keuangan (Tambunan, 2014). Apitaningrum (2017), Simanjorang (2018), Dibia dan Onwuchekwa (2013), dan Listiana dan Susilo (2012) dalam penelitiannya juga menemukan hasil yang sama. Sedangkan, Banimahd, Moradzadehfard, dan Zeynali (2012), Verawati dan Wirakusuma (2016), dan Behrouzi, Banimahd, dan Soleymani (2013) dalam pengujiannya bisa membuktikan adanya pengaruh penting dengan arah positif, serta Carbaja dan Yadnyana (2015) yang mengungkapkan pengaruh negatif yang signifikan pada variabel ini. 
Analisis Pengaruh QUOP terhadap ADL

Sesuai dengan nilai koefisien 6,429585 dan nilai signifikansi 0,0005 dimana berarti opini audit terbukti mempengaruhi keterlambatan audit dengan arah positif. Pemerolehan pendapat auditor yakni qualified opinion dilihat sebagai kabar buruk yang mana memperlambat penyelesaian audit (Turel, 2010). Santoso (2012), Apitaningrum (2017), Tambunan (2014), Lestari (2010), dan Ng dan Tai (1994) tidak mendukung hasil penelitian ini dengan pembuktian opini audit tidak signfikan. Namun hasil penelitian ini konsisten dengan penelitian Oussii dan Taktak (2018), Salleh et al. (2017), CheAhmad dan Abidin (2008), dan Ocak dan Özden (2018).

\section{Analisis Pengaruh POLC terhadap ADL}

Variabel koneksi politik yang mana memunculkan nilai signifikansi sebesar 0,1666 tidak menunjukkan adanya hasil yang signifikan. Bisa dilihat pada tabel 6 dimana frekuensi perusahaan yang terkoneksi politik hanya $6 \%$ dari keseluruhan sampel penelitian sehingga variabel ini kurang maksimal untuk menunjukkan adanya pengaruh yang kuat. Terlebih lagi, hal ini lebih tertuju pada kemampuan penggunaan waktu auditor eksternal dalam mengaudit dimana kemungkinan manipulasi nilai pada laporan keuangan yang dihasilkan bisa terjadi pada perusahaan apapun, tidak membedakan perusahaan tersebut terkoneksi politik atau tidak. Hasil ini ditunjang dengan penelitian Oussii dan Taktak (2018) yang tidak dapat membuktikan munculnya pengaruh signifikan pada variabel ini. Sedangkan bukti adanya pengaruh negatif yang signifikan ditemukan oleh pengujian Habib dan Muhammadi (2018) serta Utamaningsi (2019) yang mengungkapkan hasil pengaruh positif yang signifikan.

\section{Analisis Pengaruh SIA terhadap ADL}

Kesimpulan tidak signifikannya variabel auditor spesialis industri diwakilkan dengan nilai signifikansi sebesar 0,7354. Auditor spesialis belum tentu mempunyai kemampuan yang lebih bagus dari auditor nonspesialis, karena serangkaian kegiatan prosedur pengauditan yang banyak dan memakan waktu tetap perlu dilaksanakan oleh auditor spesialis maupun auditor yang bukan spesialis (Hanasari, 2018). Pembuktian oleh Durand (2018), Hanasari (2018), Rahadianto (2012) dan Abidin dan Ahmad-Zaluki (2012) sesuai dengan hasil penelitian ini dimana variabel auditor spesialis industri tidak berpengaruh pada keterlambatan audit. Namun pendapat lain diungkapkan oleh Rustiarini dan Sugiarti (2013), Dewi dan Hadiprajitno (2017), Putri dan Januarti (2014), Habib dan Bhuiyan (2011), dan Evans dan Rusmin (2017) yang menemukan hasil negatif dan signifikan pada variabel ini.

\section{Uji Koefisien Determinasi}

Dalam kaitannya dengan tabel 12 di atas, memiliki maksud sebesar 64,65\% keterlambatan audit bisa diterangkan oleh variabel independen yang tertera dalam model penelitian ini, dan $35,35 \%$ selebihnya berasal dari variabel luar model penelitian ini.

Tabel 12

Hasil Uji Koefisien Determinasi

\begin{tabular}{lc}
\hline Dependent Variable & Adjusted R Square \\
\hline Keterlambatan Audit & 0,6465 \\
\hline Sumber: Data sekunder diolah (2019)
\end{tabular}

\section{KESIMPULAN DAN SARAN Kesimpulan}

Penelitian ini bermaksud mengkaji kemungkinan adanya pengaruh penting dari variabel independen berupa keahlian keuangan komite audit, independensi komite audit, ukuran komite audit, pertemuan komite audit, piagam komite audit, profitabilitas, ukuran perusahaan, konsentrasi kepemilikan, pergantian 
auditor, opini audit, koneksi politik, dan auditor spesialis industri pada variabel dependen yang tidak lain, merupakan keterlambatan audit. Sesuai dengan ulasan hasil pengujian variabel dengan sampel penelitian yang dipilih dengan kriteria tertentu sebelumnya, maka hasil dari analisis penelitian yang diperoleh yakni:

1. Adanya pengaruh signifikan dengan arah negatif dari ukuran komite audit, profitabilitas, dan ukuran perusahaan pada keterlambatan audit.

2. Adanya pengaruh signifikan dengan arah positif dari opini audit pada keterlambatan audit.

3. Tidak terbuktinya pengaruh signifikan dari keahlian keuangan komite audit, piagam komite audit, pertemuan komite audit, independensi komite audit, konsentrasi kepemilikan, pergantian auditor, koneksi politik, dan auditor spesialis industri pada keterlambatan audit.

\section{Saran}

Sejumlah rekomendasi yang bisa dipaparkan oleh penulis untuk penelitian yang dilakukan lebih lanjut yakni penambahan waktu penelitian yang lebih panjang dimana melebihi 5 tahun. Kemudian, penelitian selanjutnya dapat dilakukan dengan membandingkan beberapa negara yang berbeda. Peneliti lain kedepannya juga diharapkan menggunakan variabel bebas yang lebih banyak berskala rasio daripada pemakaian variabel dummy.

\section{UCAPAN TERIMAKASIH}

Penulis mengucapkan terima kasih kepada sejumlah rekan dan saudara yang telah terlibat baik secara langsung maupun tidak langsung dalam penyelesaian penelitian ini.

\section{DAFTAR PUSTAKA}

Abdelsalam, O. H., \& Street, D. L. (2007). Corporate governance and the timeliness of corporate internet reporting by U.K. listed companies. Journal of International Accounting, Auditing and Taxation, 16(2), 111130.

Abdulla, J. Y. A. (1996). The timeliness of Bahrain annual reports. Advances in Accounting, 9, 73-88.

Abdullah, S. (2007). Board composition, audit committee and timeliness of corporate financial reports in Malaysia, 4(2), 33-45.

Abernathy, J. L., Beyer, B., Masli, A., \& Stefaniak, C. (2014). The association between characteristics of audit committee accounting experts, audit committee chairs, and financial reporting timeliness. Advances in Accounting, 30(2), 283-297. https://doi.org/10.1016/j.adiac.2014.0 9.001

Abidin, S., \& Ahmad-Zaluki, N. A. (2012). Auditor industry specialism and reporting timeliness. Procedia Social and Behavioral Sciences, 65(ICIBSoS), 873-878. https://doi.org/10.1016/j.sbspro.2012. 11.213

Afify, H. A. E. (2009). Determinants of audit report lag: does implementing corporate governance have any impact? empirical evidence from Egypt. https://doi.org/10.1108/09675420910 963397

Ahmed, M. I., \& Che-Ahmad, A. (2016). Effects of board size, board committees characteristics and audit quality on audit report lags. The European Proceedings of Social and Behaviourial Sciences, 6(2009), 810818.

Akbar, F. N., \& Kiswara, E. (2014). Efektivitas komite audit terhadap ketepatan waktu pelaporan keuangan. Diponegoro Journal of Accounting, 3, 
$1-9$.

Al-Ghanem, W., \& Hegazy, M. (2011). An empirical analysis of audit delays and timeliness of corporate financial reporting in Kuwait. Eurasian Business Review, 1(1), 73-90. https://doi.org/10.14208/BF03353799

Al-tahat, S. S. Y. (2015). Timeliness of audited financial reports of Jordanian listed companies. IPASJ International Journal of Management (IIJM), 3(2), 39-47. Retrieved from http://www.ipasj.org/IIJM/IIJM.htm

Alkhatib, K., \& Marji, Q. (2012). Audit reports timeliness: empirical evidence from Jordan. Procedia - Social and Behavioral Sciences, 62, 1342-1349. https://doi.org/10.1016/j.sbspro.2012. 09.229

Andhikari, A., Chek, D., \& Hao, Z. (2006). Public policy, political connections and effective tax rates: longitudinal evidence from Malaysia. Journal of Accounting and Public Policy, 25, 574-995.

Anugrah, E. Y., \& Laksito, H. (2017). Pengaruh efektivitas komite audit terhadap ketepatan waktu pelaporan (studi empiris pada perusahaan non keuangan terdaftar di BEI tahun 2015). Diponegoro Journal of Accounting, 6(4), 32-44.

Apadore, K., \& Mohd Noor, M. (2013). Determinants of audit report lag and corporate governance in Malaysia. International Journal of Business and Management, 8(15), 151-163. https://doi.org/10.5539/ijbm.v8n15p1 51

Apitaningrum, A. (2017). Pengaruh pergantian auditor, opini audit, ukuran perusahaan, dan laba rugi terhadap audit report lag (studi empiris pada perusahaan manufaktur yang terdaftar di Bursa Efek Indonesia periode 2011-2015).

Apriyana, N. (2017). Pengaruh profitabilitas, solvabilitas, ukuran perusahaan, dan ukuran KAP terhadap audit delay pada perusahaan properti dan real estate yang terdaftar di Bursa Efek Indonesia periode 2013-2015, l(1), 1188-1197. https://doi.org/10.1111/j.14697610.2010.02280.x

Arifa, A. N. (2013). Pengembangan model audit delay dengan audit report lag dan total lag. Accounting Analysis Journal, 2(2), 172-181. https://doi.org/10.15294/aaj.v2i2.144 1

Baatwah, S. R., Salleh, Z., \& Ahmad, N. (2015). CEO characteristics and audit report timeliness: do CEO tenure and financial expertise matter?. Journal of Managerial Psychology, Vol. 30 No, 645-658.

https://doi.org/http://dx.doi.org/10.11 08/02683940010305270

Baldacchino, P. J., Grech, L., Farrugia, K., \& Tabone, N. (2016). An analysis of audit report lags in Maltese companies. Contemporary Studies in Economic and Financial Analysis, 98, 161-182.

https://doi.org/10.1108/S1569375920160000098010

Banimahd, B., Moradzadehfard, M., \& Zeynali, M. (2012). Audit report lag and auditor change: evidence from Iran, 2(12), 12278-12282.

Basuony, M. A. K., Mohamed, E. K. A., Hussain, M. M., \& Marie, O. K. (2016). Board characteristics, ownership structure and audit report lag in the Middle East. International Journal of Corporate Governance, $7(2)$, 180. https://doi.org/10.1504/ijcg.2016.078 388

Bédard, J., Chtourou, S. M., \& Courteau, L. (2004). The effect of audit committee expertise, independence, and activity on aggressive earnings management. Auditing, 23(2), 13-35. https://doi.org/10.2308/aud.2004.23.2 .13 
Behrouzi, A., Banimahd, B., \& Soleymani, A. (2013). Audit fees and timeliness of accounting information: evidence from Iran, 3(6), 481-487.

Carslaw, C. A. P. N., \& Kaplan, S. E. (1991). An examination of audit delay: further evidence from New Zealand. Accounting and Business Research, 21-32.

Dyer, J. C., \& Mchugh, A. J. (1975). The timeliness of the Australian annual report. Journal of Accounting Research, 13(2), 204-219.

Carbaja, L. K. I. C., \& Yadnyana, I. K. (2015). Pengaruh profitabilitas, ukuran perusahaan, reputasi KAP, dan pergantian auditor pada ketidaktepatwaktuan pelaporan keuangan. E-Jurnal Akuntansi, 13(2), 615-624.

Chambers, A. E., \& Penman, S. H. (1984). Timeliness of reporting and the stock price reaction to earnings announcements. Journal of Accounting Research, 22(1), 21. https://doi.org/10.2307/2490700

Che-Ahmad, A., \& Abidin, S. (2008). Audit delay of listed companies: a case of Malaysia. International Business Research, 1(4), 32-39. https://doi.org/10.5539/ibr.v1n4p32

Dabor, A. O., \& Mohammed, F. (2015). Determinants audit delay in the Nigerian banking sector, 4, 74-91.

Dao, M., \& Pham, T. (2014). Audit tenure, auditor specialization and audit report lag. Managerial Auditing Journal, 29(6), 490-512. https://doi.org/10.1108/MAJ-072013-0906

Daoud, K. A. Al, Ismail, K. N. I. K., \& Lode, N. A. (2014). The timeliness of financial reporting among Jordanian companies: do company and board characteristics, and audit opinion matter?, (July). https://doi.org/10.5539/ass.v10n13p1 91
Darsono, D. T. A. (2017). Analisis faktorfaktor yang berpengaruh terhadap audit report lag (studi empiris pada perusahaan yang terdaftar di Bursa Efek Indonesia tahun 2013-2015), 6(4), 237-251.

Davies, B., \& Whittred, G. P. (1980). The association between selected corporate attributes and timeliness in corporate reporting: further analysis. Abacus, 16(1), 48-60. https://doi.org/10.1111/j.14676281.1980.tb00085.x

Dewi, I. C., \& Hadiprajitno, P. B. (2017). Pengaruh audit tenure dan kantor akuntan publik (KAP) spesialisasi manufaktur terhadap audit report lag (ARL). Diponegoro Journal of Accounting, 6(4), 1-12.

Dibia, D. N. ., \& Onwuchekwa, J. . (2013). An examination of the audit report lag of companies quoted in the Nigeria Stock Exchange, 8-16.

Durand, G. (2018). The determinants of audit report lag: a meta-analysis.

Efobi, U., \& Okougbo, P. (2014). Timeliness of financial reporting in Nigeria. South African Journal of Accounting Research, 28(1), 65-77. https://doi.org/10.1080/10291954.201 4.11463127

Ettredge, M., Li, C., \& Sun, L. (2005). Internal control quality and audit delay in the SOX era. Retrieved from http://papers.ssrn.com/sol3/papers.cf m?abstract_id $1 / 4794669$

Evans, J., \& Rusmin, R. (2017). Asian review of accounting article information: Asian Review of Accounting Asian Review of Accounting Asian Review of Accounting, 23(3), 232-255. https://doi.org/10.1108/ARA-042012-0017

Ghafran, C., \& Yasmin, S. (2017). Audit committee chair and financial reporting timeliness: a focus on financial, experiential and monitoring expertise. International Journal of 
Auditing,

22(1),

$13-24$.

https://doi.org/10.1111/ijau.12101

Güleç, Ö. F. (2017). Timeliness of corporate reporting in developing economies: evidence from Turkey. Journal of Accounting and Management Information Systems, 16(3), 219-239. https://doi.org/10.24818/jamis.2017.0 3001

Habib, A., \& Bhuiyan, M. B. U. (2011). Audit firm industry specialization and the audit report lag. Journal of International Accounting, Auditing and Taxation, 20(1), 32-44. https://doi.org/10.1016/j.intaccaudtax. 2010.12.004

Habib, A., \& Muhammadi, A. H. (2018). Political connections and audit report lag: Indonesian evidence. International Journal of Information Management, 36(3), 425-432. https://doi.org/10.1016/j.ijinfomgt.20 16.01.007

Hanasari, R. Y. (2018). Pengaruh reputasi KAP, opini auditor, pergantian auditor dan spesialisasi auditor terhadap audit delay.

Handayani, Y. D., \& Yustikasari, Y. (2017). Corporate governance and audit report lags at manufacturing companies in the industrial sector of consumption goods, 9(29), 24-32.

Hashim, U. J. B., \& Rahman, R. B. A. (2011). Audit report lag and the effectiveness of audit committee among malaysian listed companies. International Bulletin of Business Administration, 10(10), 50-61.

Hastuti, J., \& Meiranto, W. (2017). Pengaruh efektivitas komite audit terhadap ketepatan waktu penyampaian laporan keuangan. Diponegoro Journal of Accounting, 6 , $1-15$.

Ilaboya, O. J., \& Christian, I. (2014). Corporate governance and audit report lag in Nigeria. Asian Academy of Management Journal of
Accounting and Finance, 6(2), 57-84. Indriantoro, N., \& Supomo, B. (2009). Metodologi Penelitian Bisnis Untuk Akuntansi \& Manajemen. Yogyakarta, Indonesia: BPFE Yogyakarta.

Iskandar, M. J., \& Trisnawati, E. (2010). Faktor-faktor yang mempengaruhi audit report lag pada perusahaan yang terdaftar di Bursa Efek Indonesia. Jurnal Bisnis Dan Akuntansi, 12(3), 175-186.

Ismail, H., Mustapha, M., \& Ming, C. O. (2012). Timeliness of audited financial reports of Malaysian listed companies, 3(22), 242-247.

Jensen, M. C., \& Meckling, W. H. (1976). Theory of the firm: manajerial behaviour, ageny cost and ownership structure. Journal of Financial Economics, 3, 305-360.

Kartika, A. (2009). Faktor-faktor yang mempengaruhi audit delay di Indonesia. Telegram \& Gazette, 16(1), C1.

Khoufi, N., \& Khoufi, W. (2018). An empirical examination of the determinants of audit report delay in France. Managerial Auditing Journal, 33(8-9), 700-714. https://doi.org/10.1108/MAJ-022017-1518

Knechel, W., \& Payne, J. (2001). Additional evidence on audit report lag. Auditing: A Journal of Practice and Theory, 20(1), 137-146.

Kusuma, A. P. (2014). Analisis pengaruh efektivitas komite audit terhadap jangka waktu penyampaian laporan keuangan.

Lestari, D. (2010). Analisis faktor-faktor yang mempengaruhi audit delay dan keterlambatan publikasi laporan keuangan pada perusahaan consumer goods yang terdaftar di Bursa Efek Indonesia. Jae (Jurnal Akuntansi Dan Ekonomi), 3(1), 63. https://doi.org/10.29407/jae.v3i1.120 09 
Listiana, L., \& Susilo, T. P. (2012). Faktor-faktor yang memengaruhi reporting lag perusahaan, 2(1).

Mantik, I. M. N. S., \& Sujana, E. (2011). Analisis faktor yang mempengaruhi audit delay pada perusahaan food and beverages tercatat di BEI 2009-2011. Jurnal Berkala Ilmiah Akuntansi.

Mohamad-Nor, M. N., Shafie, R., \& WanHussin, W. N. (2010). Corporate governance and audit report lag in Malaysia, 6(2), 57-84.

Murdiawati, D. (2016). Faktor-faktor yang mempengaruhi audit report lag pada sektor properti dan real estate yang terdaftar di Bursa Efek Indonesia periode 2012-2014, 16-33.

Nelson, S. P., \& Shukeri, S. N. (2011). Corporate governance and audit report timeliness: evidence from Malaysia. Research in Accounting in Emerging Economies (Vol. 11). Emerald Group Publishing Ltd. https://doi.org/10.1108/S14793563(2011)0000011010

Ng, P. P. H., \& Tai, B. Y. K. (1994). An empirical examination of the determinants of audit delay in Hong Kong. The British Accounting Review, 26(1), 43-59. https://doi.org/10.1006/bare.1994.100 5

Noeryanto, H. (2015). Faktor-faktor yang berpengaruh terhadap audit report lag pada perusahaan non keuangan. Jurnal Bisnis Dan Akuntansi, 2(2).

Nugroho, S. F., \& Rahadian, Y. (2013). Audit committee effectiveness and its relation to audit report lag.

Ocak, M., \& Özden, E. A. (2018). Signing auditor-specific characteristics and audit report lag: a research from Turkey. Journal of Applied Business Research, 34(2), 277-294. https://doi.org/10.19030/jabr.v34i2.10 129

Okalesa. (2018). Analisis pengaruh ukuran perusahaan, roa, dan dar terhadap audit delay (studi empiris pada perusahaan sektor industri barang konsumsi yang terdaftar di Bursa Efek Indonesia tahun 2011-2016. Journal of Economic, Business and Accounting, 1(2), 221-232.

Oussii, A. A., \& Taktak, N. B. (2018). Audit committee effectiveness and financial reporting timeliness: the case of Tunisian listed companies. African Journal of Economic and Management Studies, 9(1), 34-55. https://doi.org/10.1108/AJEMS-112016-0163

Ozoanigbo, C. V., Orjinta, I. O., \& Ofor, T. N. (2016). Audit committee effectiveness and timeliness of the financial reporting in Nigeria. Approaches in International Journal of Research Development, 10(1), 113.

Purwati, A. S. (2006). Pengaruh karakteristik komite audit terhadap ketepatan waktu pelaporan keuangan pada perusahaan publik yang tercatat di BEI.

Putri, A. N. I., \& Januarti, I. (2014). Faktor - faktor yang berpengaruh terhadap audit report lag pada perusahaan anufaktur yang terdaftar di Bursa Efek Indonesia periode tahun 20082012. Diponegoro Journal of Accounting, 3(2), 64-73.

Rahadianto, N. A. (2012). Analisis pengaruh auditor spesialisasi industri, dewan komisaris, komite audit, dan penerapan PSAK 50/55 (revisi 2006) terhadap audit delay pada industri perbankan.

Raweh, N. A. M., Kamardin, H., \& Malik, M. (2019). Audit committee characteristics and audit report lag: evidence from Oman. International Journal of Accounting and Financial Reporting, $\quad 9(1), \quad 152$. https://doi.org/10.5296/ijafr.v9i1.141 70

Rianti, N. L. P. A. E., \& Sari, M. M. R. (2014). Karakteristik komite audit dan audit delay. E-Jurnal Akuntansi 
Universitas Udayana, 6(3), 488-508.

Rustiarini, N. W., \& Sugiarti, N. W. M. (2013). Pengaruh karakteristik auditor, opini audit, audit tenure, pergantian auditor pada audit delay, 657-675.

Sakka, I. F., \& Jarboui, A. (2015). External auditor's characteristics, corporate governance and audit reporting quality. International Journal of Accounting and Economics Studies, 3(2), 109. https://doi.org/10.14419/ijaes.v3i2.48 45

Salleh, Z., Baatwah, S. R., \& Ahmad, N. (2017). Audit committee financial expertise and audit report lag: Malaysia further insight. Asian Journal of Accounting and Governance, $\quad 8, \quad$ 137-150. https://doi.org/10.17576/AJAG-201708-12

Samaha, K., \& Khlif, H. (2017). Auditrelated attributes, regulatory reforms and timely disclosure. Journal of Financial Reporting and Accounting, 15(2), 158-179. https://doi.org/10.1108/JFRA-082015-0077

Santoso, F. K. (2012). Analisis faktorfaktor yang mempengaruhi audit delay pada perusahaan di sektor keuangan, 1(3).

Santoso, S. (2012). Statistik Parametik. Jakarta: PT Gramedia Pustaka Umum.

Setiawan, G., \& Nahumury, J. (2014). The effect of board of commissioners, audit committee, and stock ownership concentration on audit report lag of banking companies in Indonesia Stock Exchange. The Indonesian Accounting Review, 4(01), 15. https://doi.org/10.14414/tiar.v4i01.28 0

Shukeri, S. N., \& Islam, M. A. (2012). The determinants of audit timeliness: evidence from Malaysia. Journal of Applied Sciences Research, 8(7),
3314-3322.

Simanjorang, R. M. (2018). Pengaruh profitabilitas, opini audit, pergantian auditor, dan ukuran perusahaan terhadap audit report lag pada perusahaan manufaktur di Bursa Efek Indonesia periode 2014-2016. Jurnal Ilmiah Bisnis Dan Ekonomi Asia, 11(1), 64-70. https://doi.org/10.32812/jibeka.v11i1. 34

Sultana, N., Singh, H., \& Van der Zahn, J.L. W. M. (2015). Audit committee characteristics and audit report lag. International Journal of Auditing, 19(2), $72-87$. https://doi.org/10.1111/ijau.12033

Susanti, K. (2018). Pengaruh karakteristik komite audit dan karakteristik perusahaan terhadap ketepatan waktu penyampaian laporan keuangan.

Sutapa, I. N., \& Wirakusuma, M. G. (2013). Pengaruh faktor internal dan eksternal perusahaan terhadap audit delay, 525-543.

Sutikno, Y. M., \& Hadiprajitno, P. B. (2015). Analisis faktor internal dan eksternal yang berpengaruh terhadap audit report lag. Diponegoro Journal of Accounting, 4(Entrepreneurship), 510-517.

Swami, N. P. D., \& Latrini, M. Y. (2013). Pengaruh karakteristik corporate governance terhadap audit report lag. E-Jurnal Akuntansi, 4(3), 530-549.

Tambunan, P. U. (2014). Pengaruh opini audit, pergantian auditor dan ukuran kantor akuntan publik terhadap audit report lag (studi empiris pada perusahaan manufaktur yang terdaftar di Bursa Efek Indonesia). Jurnal Akuntansi Universitas Negeri Padang, 3(1).

Turel, A. (2010). Timeliness of financial reporting in emerging capital markets: evidence from Turkey, (29799).

Utamaningsi, L. (2019). Political connection, auditor selection, audit 
fee $\&$ audit report lag: a review in Indonesia, 13(2), 167-173.

Verawati, N., \& Wirakusuma, M. (2016). Pengaruh pergantian auditor, reputasi KAP, opini audit, dan komite audit dalam audit delay. E-Jurnal Akuntansi, 17(2), 1083-1111.

Wardhani, A. P. (2013). Analisis pengaruh karakteristik corporate governance terhadap audit report lag. E-Jurnal Akuntansi.

Wardhani, A. P., \& Raharja, S. (2013). Analisis pengaruh corporate governance terhadap audit report lag. DiponegoroJournal Of Accounting, 2, $1-11$.

Widosari, S. A. (2012). Analisis faktorfaktor yang berpengaruh terhadap audit delay pada perusahaan manufaktur di Bursa Efek Indonesia tahun 2008-2010. Jurnal REKSA: Rekayasa Keuangan, Syariah dan Audit.

https://doi.org/10.12928/j.reksa.v1i2. 9

Widyaswari, K. R., \& Suardana, K. A. (2014). Pengaruh karakteristik komite audit terhadap timeliness pelaporan keuangan: perusahaan go public yang terdaftar di Bursa Efek Indonesia. EJurnal Akuntansi Universitas Udayana, 1, 154-166.

Wijayanto, B. D. (2016). Pengaruh ukuran perusahaan, umur perusahaan, profitabilitas perusahaan, solvabilitas perusahaan, dan ukuran KAP terhadap audit report lag (pada perusahaan perbankan yang terdaftar di Bursa Efek Indonesia periode 2012-2014). IOSR Journal of Economics and Finance. https://doi.org/https://doi.org/10.3929 /ethz-b-000238666

Yadirichukwu, E., \& Ebimobowei, A. (2013). Audit committee and timeliness of financial reports: empirical evidence from Nigeria. Journal of Economics and Sustainable Development, 4(20),
2222-1700. Retrieved from www.iiste.org

Yunos, R. M. (2017). The relevance of internal overnance mechanisms to financial reports timeliness. Management \& Accounting Review, 16(2), 213-234. 